\title{
EVALUATION OF SERUM TOLL-LIKE RECEPTOR 4 AND NUCLEAR FACTOR-KBP65 PROTEINS IN ORAL SQUAMOUS CELL CARCINOMA
}

\author{
JAYALALITHA SATHIYAMOORTHY ${ }^{1}$, VIDYARANI SHYAMSUNDAR ${ }^{2}$, N. ARAVINDHA BABU ${ }^{2}$, \\ SUBBAIH SHANMUGAM ${ }^{3}$, JAGADEESAN. G. MANI ${ }^{3}$, PONNURAJA CHINNAIYAN ${ }^{4}$, RAJESWARY HARI ${ }^{1 *}$
}

${ }^{1}$ Department of Biotechnology, Dr. M.G.R. Educational and Research Institute, Chennai, Tamil Nadu, India. ${ }^{2}$ Department of Oral Pathology and Microbiology Centre of Oral Cancer Prevention and Research, Sree Balaji Dental College and Hospital, Bharath Institute of HigherEducation,

Chennai, Tamil Nadu, India. ${ }^{3}$ Department of Surgical Oncology, Government Royapettah Hospital and Kilpauk Medical College, Chennai, Tamil Nadu, India. ${ }^{4}$ Department of Statistics, National Institute of Research in Tuberculosis, Chennai, Tamil Nadu, India. Email: rajihar@gmail.com

Received: 03 July 2018, Revised and Accepted: 25 July 2018

ABSTRACT

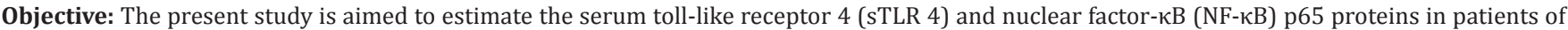
oral squamous cell carcinoma (OSCC).

Methods: The study was performed in prospective cases of 22 OSCC patients, 10 oral epithelial dysplasia patients, 8 control with chewing habits, and 4 control patients. The estimation of sTLR 4 and NF-кBp65 proteins was done by enzyme-linked immunosorbent assay method. The Pearson correlation test was performed to find out the relationship between these two proteins.

Results: There was an increase in the sTLR 4 protein level in study groups OSCC, oral premalignant disorders, control with chewing habits, and control habits such as $1.31 \mathrm{ng} / \mathrm{ml} \pm 1.06 \mathrm{ng} / \mathrm{ml}, 1.99 \mathrm{ng} / \mathrm{ml} \pm 0.98 \mathrm{ng} / \mathrm{ml}$, and $2.11 \mathrm{ng} / \mathrm{ml} \pm 0.61 \mathrm{ng} / \mathrm{ml}$, respectively, when comparable ( $\mathrm{p}=0.008)$ to control patients with $0.60 \mathrm{ng} / \mathrm{ml} \pm 0.24 \mathrm{ng} / \mathrm{ml}$. However, in the case of serum level NF- $\mathrm{\kappa Bp} 65$ protein all the study groups including the control showed same values. The Pearson correlation test showed significant relationship $\left(r_{\text {pearson }}=0.91\right.$, [p<0.0005]) of these two proteins only in the OSCC patients.

Conclusion: It can be concluded that serum levels of TLR 4 are increased in OSCC patients, but there was no variation seen for the NF-кBp65 protein. There is a strong interrelationship exist between the serum levels of TLR 4 and NF- $\mathrm{kBp} 65$ proteins in the OSCC patients only.

Keywords: Oral squamous cell carcinoma, Oral epithelial dysplasia, Enzyme-linked immunosorbent assay, Toll-like receptor 4, Nuclear Factor-кBP65.

(c) 2018 The Authors. Published by Innovare Academic Sciences Pvt Ltd. This is an open access article under the CC BY license (http://creativecommons. org/licenses/by/4. 0/) DOI: http://dx.doi.org/10.22159/ajpcr.2018.v11i12.28234

\section{INTRODUCTION}

Oral cancer, malignant neoplasm ranks $3^{\text {rd }}$ among the cancer types with a prevalence of $45 \%$ in India and about $90-95 \%$ of squamous cell carcinoma is the $12^{\text {th }}$ most prevalent neoplasm globally [1-4]. Oral squamous cell carcinoma (OSCC) constitutes more than $90 \%$ of head and neck malignancies and ranks $6^{\text {th }}$ among all other cancers which are the cause for high morbidity and mortality worldwide with an high incidence rate that varies widely by geographic location $[5,6]$. However, nearly $3-6 \%$ of the OSCC patients were predominantly observed in the western countries, while the rate was higher with $30 \%$ among the east including Indonesia [7]. Rapid cell division leads to clinical hypoxia causing the releases of pro-inflammatory mediators that, in turn, enlist inflammatory cells. In particular, nuclear factor- $\mathrm{\kappa B}$ (NF- $\mathrm{\kappa B}$ ) which acts as an important intermediate between inflammation and cancer $[8,9]$ also exerts dual action of both protumorigenic and cell survival mechanism [10,11]. Hence, it is considered as valuable therapeutic target [12]. Its activation is mediated by three molecules such as toll-like receptors (TLRs), interleukin-1 receptor, and the tumor NF receptor. TLRs, type I transmembrane protein identifies conserved microbial structures/ patterns and was previously thought to play a critical role in host defense against wide range of organisms from bacteria to protozoa [13]. Recently, it is known that many cancer cells express TLRs and till now, 13 mammalian TLRs have been demonstrated, but in humans, only 11 are expressed. Recent data had demonstrated that OSCC could modulate TLRs protein expression and function in variety of immune cells [14]. Hence, TLR role in rapid cell proliferation and metastasis of oral cancer was established. The association of TLRs with NF-kBp65 with different malignancies in patients with OSCC was also described $[15,16]$. However, the mechanism behind the interactions was not completely understood.
Many molecular markers had been proposed for the better survival of OSCC patients, but none are available in clinical benefit. Hence, early identification of ideal therapeutic targets is mandatory. Studies pertaining to the relationship of serum TLR 4 (sTLR 4) and serum NF- $\mathrm{KB}$ (sNF-kB) p65 for OSCC are considered to be inadequate. Hence, the objective of the study is to analyze the sTLR 4 and sNF-kBp65 level in our samples using enzyme-linked immunosorbent assay (ELISA) to identify diagnostic and as well as prognostic values in our study populations.

\section{METHODS}

\section{Subject characteristics}

The study was approved by the Institution Ethics Committee of (a) A.C.S Medical College, Chennai, (b) Sree Balaji Dental College and Hospital, Chennai, and (c) Government Tertiary Care Centre, Chennai. The written informed consent was obtained from all the patients $(n=44)$ for the prospective samples by surgical oncologist and dental surgeons, respectively. Patient details were collected based on the structured questionnaire and blood samples were obtained from patients which includes OSCC and oral premalignant disorders (OPMDs) control with chewing habits and absolute control samples.

\section{Sample collection and ELISA for TLR 4 and NF-KB p65 proteins} Peripheral blood samples were obtained from patients under aseptic condition and collected in non-heparinized tubes. The serum was separated by centrifuging the samples at $1000 \mathrm{rpm}$ for $15 \mathrm{~min}$. The samples were stored at -80 until further use. ELISA was performed with the help of commercially available human TLR 4 (Catalog No: E-EL-H1539, ELabscience, USA) and NF- $\mathrm{B}$ p65 (Catalog No: E-EL-H1388), by following manufacturing instruction. Optical density was determined of each microtiter well and plate was read at $450 \mathrm{~nm}$ using ELISA reader. 
Statistical analysis

All statistical analyses were performed with the help of Statistical Package for the Social Sciences version 20.0 (Chicago, IL, USA). Numerical data were expressed as the mean \pm standard deviation. The comparisons of numerical data were performed by independent sample t-test, categorical variables were performed with Chi-square test or Fisher's exact test and Mann-Whitney test for continuous variables was used. The correlation between sTLR 4 and sNF- $\mathrm{Bp} 65$ level was calculated using Pearson correlation. $\mathrm{p}<0.05$ was considered to be statistically significant.

\section{RESULTS}

Baseline characteristics of different study group patients

The baseline clinical characteristics of the study populations are given below. Both male and female were grouped as OSCC $(n=22)$, oral epithelial dysplasia (OED) ( $n=10)$, control with chewing habits $(n=8)$, and absolute control patients $(n=4)$. Overall, the mean age of the study group for each population was between 48.3 years for OSCC(ranged 33-69 years), 47.2 years for OED(ranged 32-64 years), 50 years for Control with chewing habits(ranged 33-65 years), and 49.7 years(ranged 33-80 years) for absolute control patients. When considering the gender, $81.8 \%$ of patients belong to male populations and only $18.2 \%$ of patients were categorized as female patients. When the tobacco consumption is considered $77.3 \%$ in OSCC, $90 \%$ in OED, and $100 \%$ in control with chewing habits, patients were found to be the active tobacco users against the control patients with nil tobacco consumptions. Tobacco users in the form of smoking habits are considered, OSCC 40.9\%, OED 60\%, and nil in control with chewing habits, and control patients were included for the study. Among the OSCC patients and OED patients, $18.2 \%$ and $60 \%$ were had the habits of alcohol consumption against the control with chewing habits and absolute control with no alcohol usage.
Correlation of serum level expression of sTLR 4 with baseline characteristics of different study group patients

In the present investigation, sTLR 4 levels were found to be increased in OSCC, OPMD, and control with chewing habit patients when comparable to absolute control patients (Table 1) which may be correlated with their tobacco usage. In the present investigation, age group of $>45$ showed an increased level of sTLR 4 in all the study groups when compared to the age groups of $\leq 45$. While considering the gender, both male and female populations exhibited almost the same levels in all the study populations. In the present investigation, it was noticed that non-smokers had a high level of sTLR 4 when compared to smokers in all the study population. Similarly, all habitual users exhibited high level of TLR 4 in OSCC patients and non-habitual users exhibited high level of TLR 4 in OED patients. The control with chewing habits and absolute control patients we could not do proper comparison as far as smoking habit, alcohol, and non-chewing habits is concerned since the cases were significantly less. The alcohol users exhibited high level of TLR 4 when comparable to non-alcoholic users (OSCC $p=0.280$ and OED $p=0.057$ ). Since it is a customary to do the TNM staging only for OSCC, we analyzed the correlations of the levels of the TLR 4 to the TNM staging in OSCC patients alone. It is observed that patients belonging to T4 stage have an increased level of sTLR 4 when comparable to the patients in the stage of $\mathrm{T} 2$.

Correlation of serum level expression of sNF- $\mathrm{kBp} 65$ in with baseline characteristics of different study group patients

In the present investigation, there is no significant variation in the sNF$\kappa B p 65$ levels was found among the study population such as OSCC, OPMD, and control with chewing habits and absolute control patients (Table 2). Similar to TLR 4 age group of $>45$ showed an increased level of Nfkpb65 in all study groups. While considering the gender, female population showed high level of sNF-кBp65 when compared to male populations $(\mathrm{p}=0.013)$ in OSCC patients and low level of sNF- $\mathrm{\kappa Bp} 65$ in female populations when compared to male in OED cases $(p=0.502)$.

Table 1: Quantification of STLR 4 in OSCC and OED patients

\begin{tabular}{|c|c|c|c|c|c|c|}
\hline Variable & n (\%) & $\begin{array}{l}\text { OSCC patients STLR } 4(\mathrm{ng} / \mathrm{ml}) \\
\text { mean } \pm \text { SD }\end{array}$ & p value & n (\%) & $\begin{array}{l}\text { OED patients sTLR } 4(\mathrm{ng} / \mathrm{ml}) \\
\text { mean } \pm \text { SD }\end{array}$ & $p$ value \\
\hline \multicolumn{7}{|l|}{ Age } \\
\hline$>45$ & 12 & $1.45 \pm 1.14 \mathrm{ng} / \mathrm{ml}$ & \multirow[t]{2}{*}{0.497} & 5 & $2.2 \pm 0.7 \mathrm{ng} / \mathrm{ml}$ & \multirow[t]{2}{*}{0.545} \\
\hline$\leq 45$ & 10 & $1.139 \pm 0.995 \mathrm{ng} / \mathrm{ml}$ & & 5 & $1.795 \pm 1.20 \mathrm{ng} / \mathrm{ml}$ & \\
\hline \multicolumn{7}{|l|}{ Gender } \\
\hline Male & 18 & $1.167 \pm 0.916 \mathrm{ng} / \mathrm{ml}$ & \multirow[t]{2}{*}{0.175} & 8 & $1.9 \pm 1.0 \mathrm{ng} / \mathrm{ml}$ & \multirow[t]{2}{*}{0.648} \\
\hline Female & 4 & $1.97 \pm 1.57 \mathrm{ng} / \mathrm{ml}$ & & 2 & $2.3 \pm 0.5 \mathrm{ng} / \mathrm{ml}$ & \\
\hline $\mathrm{T} 2$ & 6 & $1.248 \pm 1.35 \mathrm{ng} / \mathrm{ml}$ & \multirow[t]{2}{*}{0.864} & 0 & NA & NA \\
\hline $\mathrm{T} 4$ & 16 & $1.33 \pm 0.988 \mathrm{ng} / \mathrm{ml}$ & & 0 & NA & NA \\
\hline \multicolumn{7}{|l|}{ Smoking } \\
\hline Yes & 9 & $1.112 \pm 1.187 \mathrm{ng} / \mathrm{ml}$ & \multirow[t]{2}{*}{0.473} & 6 & $1.97 \pm 0.69 \mathrm{ng} / \mathrm{ml}$ & \multirow[t]{2}{*}{0.928} \\
\hline No & 13 & $1.454 \pm 0.998 \mathrm{ng} / \mathrm{ml}$ & & 4 & $2.03 \pm 1.44 \mathrm{ng} / \mathrm{ml}$ & \\
\hline \multicolumn{7}{|l|}{ Chewing } \\
\hline Yes & 17 & $1.443 \pm 1.116 \mathrm{ng} / \mathrm{ml}$ & \multirow[t]{2}{*}{0.305} & 9 & $2.04 \pm 1.02 \mathrm{ng} / \mathrm{ml}$ & \multirow[t]{2}{*}{0.651} \\
\hline No & 5 & $0.8744 \pm 0.815 \mathrm{ng} / \mathrm{ml}$ & & 1 & $1.54 \pm 0.0 \mathrm{ng} / \mathrm{ml}$ & \\
\hline Yes & 4 & $0.782 \pm 0.783 \mathrm{ng} / \mathrm{ml}$ & \multirow[t]{2}{*}{0.280} & 6 & $2.46 \pm 0.92 \mathrm{ng} / \mathrm{ml}$ & \multirow[t]{2}{*}{0.057} \\
\hline No & 18 & $1.432 \pm 1.101 \mathrm{ng} / \mathrm{ml}$ & & 4 & $1.29 \pm 0.60 \mathrm{ng} / \mathrm{ml}$ & \\
\hline \multicolumn{7}{|c|}{ Chewing with smokers } \\
\hline Yes & 7 & $1.36 \pm 1.027 \mathrm{ng} / \mathrm{ml}$ & \multirow[t]{2}{*}{0.742} & 5 & $2.060 \pm 0.7437 \mathrm{ng} / \mathrm{ml}$ & \multirow[t]{2}{*}{0.856} \\
\hline No & 15 & $1.200 \pm 1.22 \mathrm{ng} / \mathrm{ml}$ & & 5 & $1.93 \pm 1.267 \mathrm{ng} / \mathrm{ml}$ & \\
\hline \multicolumn{7}{|c|}{ Smoking with alcohol } \\
\hline Yes & 3 & $0.649 \pm 0.903 \mathrm{ng} / \mathrm{ml}$ & \multirow[t]{2}{*}{0.255} & 4 & $2.109 \pm 0.854 \mathrm{ng} / \mathrm{ml}$ & \multirow[t]{2}{*}{0.790} \\
\hline No & 19 & $1.41 \pm 1.07 \mathrm{ng} / \mathrm{ml}$ & & 6 & $1.92 \pm 1.13 \mathrm{ng} / \mathrm{ml}$ & \\
\hline \multicolumn{7}{|c|}{ Chewing with alcohol } \\
\hline Yes & 2 & $1.08 \pm 0.700 \mathrm{ng} / \mathrm{ml}$ & \multirow[t]{2}{*}{0.759} & 5 & $2.65 \pm 0.901 \mathrm{ng} / \mathrm{ml}$ & \multirow[t]{2}{*}{0.023} \\
\hline No & 20 & $1.33 \pm 1.106 \mathrm{ng} / \mathrm{ml}$ & & 5 & $1.34 \pm 0.532 \mathrm{ng} / \mathrm{ml}$ & \\
\hline \multicolumn{7}{|l|}{ All habits } \\
\hline Yes & 2 & $1.33 \pm 1.10 \mathrm{ng} / \mathrm{ml}$ & \multirow[t]{2}{*}{0.759} & 7 & $1.86 \pm 1.04 \mathrm{ng} / \mathrm{ml}$ & \multirow[t]{2}{*}{0.554} \\
\hline No & 20 & $1.08 \pm 0.700 \mathrm{ng} / \mathrm{ml}$ & & 3 & $2.298 \pm 0.937 \mathrm{ng} / \mathrm{ml}$ & \\
\hline
\end{tabular}

sTLR 4: Serum toll-like receptor 4, OSCC: Oral squamous cell carcinoma, OED: Oral epithelial dysplasia, SD: Standard deviation 
Table 2: Quantification of SNFKBp65 in OSCC and OED patients

\begin{tabular}{|c|c|c|c|c|c|c|}
\hline Variable & n (\%) & $\begin{array}{l}\text { OSCC patients sNF-kBp65 }(\mathrm{ng} / \mathrm{ml}) \\
\text { mean } \pm \text { SD }\end{array}$ & $p$ value & n (\%) & $\begin{array}{l}\text { OED patients sNF-kBp } 65(\mathrm{ng} / \mathrm{ml}) \\
\text { mean } \pm \text { SD }\end{array}$ & p value \\
\hline \multicolumn{7}{|l|}{ Age } \\
\hline$>45$ & 12 & $0.585 \pm 0.749 \mathrm{ng} / \mathrm{ml}$ & \multirow[t]{2}{*}{0.312} & 5 & $0.304 \pm 0.395 \mathrm{ng} / \mathrm{ml}$ & \multirow[t]{2}{*}{0.565} \\
\hline$\leq 45$ & 10 & $0.314 \pm 0.460 \mathrm{ng} / \mathrm{ml}$ & & 5 & $0.18 \pm 0.17 \mathrm{ng} / \mathrm{ml}$ & \\
\hline \multicolumn{7}{|l|}{ Gender } \\
\hline Male & 18 & $0.309 \pm 0.457 \mathrm{ng} / \mathrm{ml}$ & \multirow[t]{2}{*}{0.013} & 8 & $0.279 \pm 0.32 \mathrm{ng} / \mathrm{ml}$ & \multirow[t]{2}{*}{0.502} \\
\hline Female & 4 & $1.15 \pm 0.933 \mathrm{ng} / \mathrm{ml}$ & & 2 & $0.11 \pm 0.05 \mathrm{ng} / \mathrm{ml}$ & \\
\hline $\mathrm{T} 2$ & 6 & $0.406 \pm 0.87 \mathrm{ng} / \mathrm{ml}$ & \multirow[t]{2}{*}{0.809} & 0 & NA & NA \\
\hline $\mathrm{T} 4$ & 16 & $0.483 \pm 0.557 \mathrm{ng} / \mathrm{ml}$ & & 0 & NA & NA \\
\hline \multicolumn{7}{|l|}{ Smoking } \\
\hline Yes & 9 & $0.290 \pm 0.503 \mathrm{ng} / \mathrm{ml}$ & \multirow[t]{2}{*}{0.303} & 6 & $0.33 \pm 0.3 \mathrm{ng} / \mathrm{ml}$ & \multirow[t]{2}{*}{0.248} \\
\hline No & 13 & $0.581 \pm 0.708 \mathrm{ng} / \mathrm{ml}$ & & 4 & $0.10 \pm 0.13 \mathrm{ng} / \mathrm{ml}$ & \\
\hline \multicolumn{7}{|l|}{ Chewing } \\
\hline Yes & 17 & $0.567 \pm 0.687 \mathrm{ng} / \mathrm{ml}$ & \multirow[t]{2}{*}{0.020} & 9 & $0.2 \pm 0.3 \mathrm{ng} / \mathrm{ml}$ & \multirow[t]{2}{*}{0.554} \\
\hline No & 5 & $0.105 \pm 0.161 \mathrm{ng} / \mathrm{ml}$ & & 1 & $0.4 \pm 0.0 \mathrm{ng} / \mathrm{ml}$ & \\
\hline Yes & 4 & $0.196 \pm 0.279 \mathrm{ng} / \mathrm{ml}$ & \multirow[t]{2}{*}{0.368} & 6 & $0.33 \pm 0.3 \mathrm{ng} / \mathrm{ml}$ & \multirow[t]{2}{*}{0.248} \\
\hline No & 18 & $0.521 \pm 0.682 \mathrm{ng} / \mathrm{ml}$ & & 4 & $0.1 \pm 0.14 \mathrm{ng} / \mathrm{ml}$ & \\
\hline \multicolumn{7}{|c|}{ Chewing with smokers } \\
\hline Yes & 7 & $0.364 \pm 0.551 \mathrm{ng} / \mathrm{ml}$ & \multirow[t]{2}{*}{0.632} & 5 & $0.320 \pm 0.384 \mathrm{ng} / / \mathrm{ml}$ & \multirow[t]{2}{*}{0.456} \\
\hline No & 15 & $0.508 \pm 0.684 \mathrm{ng} / \mathrm{ml}$ & & 5 & $0.171 \pm 0.1815 \mathrm{ng} / \mathrm{ml}$ & \\
\hline \multicolumn{7}{|c|}{ Smoking with alcohol } \\
\hline Yes & 3 & $0.162 \pm 0.332 \mathrm{ng} / \mathrm{ml}$ & \multirow[t]{2}{*}{0.392} & 4 & $0.424 \pm 0.400 \mathrm{ng} / \mathrm{ml}$ & \multirow[t]{2}{*}{0.122} \\
\hline No & 19 & $0.509 \pm 0.664 \mathrm{ng} / \mathrm{ml}$ & & 6 & $0.127 \pm 0.131 \mathrm{ng} / \mathrm{ml}$ & \\
\hline \multicolumn{7}{|c|}{ Chewing with alcohol } \\
\hline Yes & 2 & $0.288 \pm 0.354 \mathrm{ng} / \mathrm{ml}$ & \multirow[t]{2}{*}{0.696} & 5 & $0.320 \pm 0.380 \mathrm{ng} / \mathrm{ml}$ & \multirow[t]{2}{*}{0.456} \\
\hline No & 20 & $0.479 \pm 0.660 \mathrm{ng} / \mathrm{ml}$ & & 5 & $0.171 \pm 0.190 \mathrm{ng} / \mathrm{ml}$ & \\
\hline \multicolumn{7}{|l|}{ All habits } \\
\hline Yes & 2 & $0.288 \pm 0.354 \mathrm{ng} / \mathrm{ml}$ & \multirow[t]{2}{*}{0.696} & 3 & $0.424 \pm 0.490 \mathrm{ng} / \mathrm{ml}$ & \multirow[t]{2}{*}{0.465} \\
\hline No & 20 & $0.479 \pm 0.660 \mathrm{ng} / \mathrm{ml}$ & & 7 & $0.169 \pm 0.164 \mathrm{ng} / \mathrm{ml}$ & \\
\hline
\end{tabular}

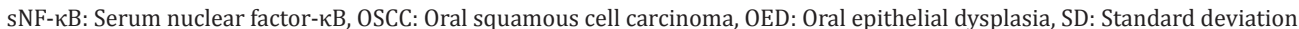

However, tobacco users had a high level of sNfkpb65 (OSCC p $=0.020$ and OED $\mathrm{p}=0.554$ ) when compared to non-tobacco users in the case of all study populations. Interestingly, increased sNfkpb65 levels were observed in non-smokers and even in non- alcohol users when compared to smokers and alcohol users in OSCC and OED patients. The control with chewing habits and absolute control patients we could not do proper comparison as far as smoking habit, alcohol, and nonchewing habits is concerned since the cases were significantly less. Since it is a customary to do the TNM staging only for OSCC, we analyzed the correlations of the levels of the TLR 4 to the TNM staging in OSCC patients alone. It is observed that patients belonging to T4 stage have an increased level of sNF-kBp65 when comparable to the patients in the stage of T2 $(p=0.809)$.

Correlation ship between sTLR 4 and sNF-кBp65 concentrations The Pearson correlation test showed that the TLR 4 expression in the serum of OSCC was positively correlated with NF-кBP65 expression $\left(r_{\text {pearson }}=0.91,[\mathrm{p}<0.0005]\right)$ was found to be statistically significant among OSCC groups (Fig. 1). In OPMD patients, TLR 4 expression in the serum was negatively correlated with NF-KBp65 expression $\left(\mathrm{r}_{\text {pearson }}=-0.08\right.$, $[\mathrm{p}=0.81]$ ). Similarly, among the control with chewing habits patients, the sTLR 4 expression was positively correlated with NF- $\mathrm{KBp} 65$ expression $\left(r_{\text {pearson }}=0.30,[p=0.70]\right)$. Among the absolute control patients, the TLR 4 expression level in serum was found to be negatively correlated with NF- $\kappa$ Bp65 expression $(\mathrm{r}$ $=-0.88,[p=0.11])$

\section{DISCUSSION}

In our present study, we have quantified the serum level of sTLR 4 and sNF- $\mathrm{KBp} 65$ in various study group populations. TLR 4 is considered as most important protein molecule which is involved in both non-specific and specific immune response $[17,18]$. TLR 4 is the important regulator of immune mechanism and is a single transmembrame non-catalytic protein which provides a microenvironment for the tumor cells to proliferate and as well to evade the immune response [19]. Recent

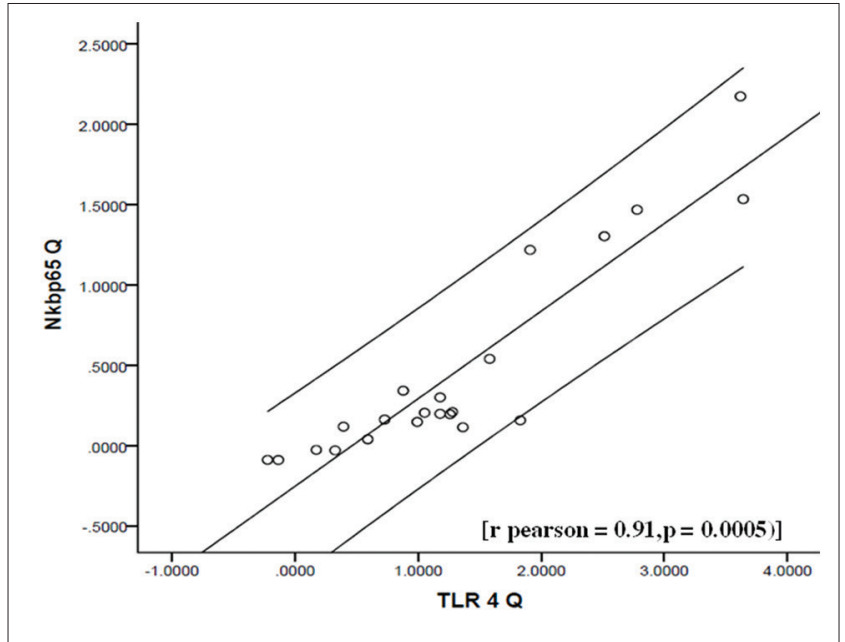

Fig. 1: Pearson correlation analysis of toll-like receptor 4 and nuclear factor-кBp65 in oral squamous cell carcinoma

studies have reported that TLRs are overexpressed in the various types of tumors. In our present investigation, significantly high TLR 4 level was observed in OSCC and control with chewing habits group of patients. Our results are comparable with studies performed by Wei et al., 2016 [20], on non-small cell lung cancer (NSCLC) patients where he showed a higher TLR 4 serum levels when compared to the healthy controls. Similarly, another study revealed from radiation pneumonia in locally advanced NSCLC exhibited higher level of TLR 4 levels in NSCLC patients when compared to healthy controls [21].

$\mathrm{NF}-\kappa \mathrm{B}$, an important key regulator for transcription factor, is the major contributor of carcinogenesis which triggers the important 
signaling pathway involved in the tumor progression such as TLR [22]. In almost all tumors such as breast, lung, and skin cancers, it is been expressed [23-25]. NF- $\mathrm{KB}$ family comprised homologous or heterologous dimers, among which the heterologous dimer of p50 and p65 is considered as most important dimer and NF- $\mathrm{kB}$ p65 plays an important nuclear transcription factor [26-28]. A study performed by Wei et al. [29] on gastric cardia adenocarcinoma showed the increased serum level of NF- $\mathrm{kBp} 65$. Similar, to the above studies performed in other cancers, our study also revealed that significant association was seen between sNF- $\mathrm{kBp} 65$ level and tobacco users. Hence, from our present study, we evaluated both levels of sTLR 4 and sNF-kBp65 expression in a relatively smaller sample size. However, there might be also some possible reason for TLR 4/NF-kB p65 activation in various factors which is not manifested in peripheral blood samples as it is rarely investigated. Hence, further studies are needed to validate with the large number of samples to evaluate sTLR 4 and sNF-kBp65 whether can be used as prognostic marker or not for OSCC patients.

\section{CONCLUSION}

To our understanding, this is our first study to report on TLR 4 and NF-

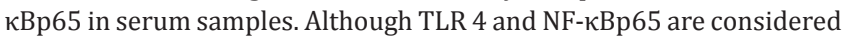
as well-known diagnostic markers, the studies pertaining to OSCC seem to be very limited. Hence, probable targeted therapy with these above markers can help in near future for OSCC patients.

\section{ACKNOWLEDGMENTS}

I thank Dr. M.G.R Educational and Research Institute, Maduravoyal, Chennai, Centre of Oral Cancer Prevention and Research, Sree Balaji Dental College and Hospital, Pallikaranai, Chennai, for providing me necessary facilities to complete this work.

\section{CONFLICTS OF INTEREST}

All authors approved the final version of the manuscript for publication.

\section{REFERENCES}

1. Williams HK. Molecular pathogenesis of oral squamous carcinoma. Mol Pathol 2000;53:165-72.

2. Elango JK, Gangadharan P, Sumithra S, Kuriakose MA. Trends of head and neck cancers in urban and rural India. Asian Pac J Cancer Prev 2006; 7:108-12.

3. Choi S, Myers JN. Molecular pathogenesis of oral squamous cell carcinoma: Implications for therapy. J Dent Res 2008;87:14-32.

4. Misra S, Chaturvedi A, Misra NC. Management of gingivobuccal complex cancer. Ann R Coll Surg Engl 2008;90:546-53.

5. Howell RE, Wright BA, Dewar R. Trends in the oral cancer in Nova Scotia from 1983 to 1997. Oral Surg Oral Med Oral Pathol Oral Radiol Endod 2003;95:205-12.

6. Hasan S, Elongovan S. Conventional and advanced diagnostic aids in oral cancer screening - The journey so far. Int J Pharm Pharm Sci 2014;7:29-33.

7. Sari LM, Subita GP, Auerkari EI. Potential antioxidant and cytotoxic activities of areca nut (Areca catechu linn.) extract in human oral squamous cell carcinoma and keratinocyte cells. Asian J Pharm Clin Res 2017;10:286-91.

8. Karin M. The Kappa kinase-a bridge between inflammation and cancer. Cell Res 2008;18:334-42.

9. Disis ML. Immune regulation of cancer. J Clin Oncol 2010;28:4531-38.
10. Ben-Neriah Y, Karin M. Inflammation meets cancer, with NF-kappaB as the matchmaker. Nat Immunol 2011;12:715-23.

11. Zhu Z, Zhong S, Shen Z. Targeting the inflammatory pathways to enhance chemotherapy of cancer. Cancer Biol Ther 2011;12:95-105.

12. Blasius AL, Beutler B. Intracellular toll-like receptors. Immunity 2010;32:305-15

13. Szczepanski MJ, Czystowska M, Szajnik M, Harasymczuk M, Boyiadzis M, Kruk-Zagajewska A. Triggering of toll-like receptor 4 expressed on human head and neck squamous cell carcinoma promotes tumor development and protects the tumor from immune attack. Cancer Res 2009;69:3105-13.

14. Min R, Zun Z, Li S, Yang W, Lizheng W, Chenping Z. Increased expression of toll-like receptor 9 has close relation with tumor proliferation in oral squamous cell carcinoma. Arch Oral Biol 2011;56:877-84.

15. Bhattacharya D, Yusuf N. Expression of toll-like receptors on breast tumors: Taking a toll on tumor microenvironment. Int J Breast Cancer 2012;2012:716564-9.

16. Shen B, Dong P, Ying XJ. Expression of ABCG2 and NFkB p65 in nasopharyngeal cancer and its clinical significance. Chinese Clin Oncol 2012;17:424-7.

17. Sautes-Fridman C, Cherfils-Vicini J, Damotte D, Fisson S, Fridman WH, Cremer I, et al. Tumor microenvironment is multifaceted. Cancer Metastasis Rev 2011;30:13-25.

18. Kelsh RM, McKeown-Longo PJ. Topographical changes in extracellular matrix: Activation of TLR4signaling and solid tumor progression. Trends Cancer Res 2013; 9:1-13.

19. Basith S, Manavalan B, Yoo TH, Kim SG, Choi S. Roles of toll-like receptors in cancer: A double-edged sword for defines and offense. Arch Pharm Res 2012;35:1297-316.

20. Wei F, Yang F, Li J, Zheng Y, Yu W, Yang L, et al. Soluble Toll-like receptor 4 is a potential serum biomarker in non-small cell lung cancer. Oncotarget 2016;7:40106-14

21. Lan F, Yue X, Ren G, Wang Y, Xia T. Serum toll-like receptors are potential biomarkers of radiation pneumonia in locally advanced NSCLC. Int J Clin Exp Pathol 2014;7:8087-95.

22. Lee CH, Jeon YT, Kim SH, Song YS. NF-kappaB as a potential molecular target for cancer therapy. Biofactors 2007,29:19-35.

23. Sovak MA, Bellas RE, Kim DW, Zanieski GJ, Rogers AE, Traish AM, et al. Aberrant nuclear factor-kb/Rel expression and the pathogenesis of breast cancer. J Clin Invest 1997;100:2952-60.

24. Mukhopadhyay T, Roth JA, Maxwell SA. Altered expression of the p50 subunit of the NF-kappa B transcription factor complex in non-small cell lung carcinoma. Oncogene 1995;11:999-1003.

25. Bell S, Degitz K, Quirling M, Jilg N, Page S, Brand K. Involvement of NF-kappaB signalling in skin physiology and disease. Cell Signal 2003;15:1-7.

26. Oeckinghaus A, Ghosh S. The NF- $\mathrm{kB}$ family of transcription factors and its regulation. Cold Spring Harbor Perspect Biol 2009;1:a000034.

27. Siggers T, Chang AB, Teixeira A, Wong D, Williams KJ, Ahmed B, et al. Principles of dimer-specific gene regulation revealed by a comprehensive characterization of NF- $\mathrm{kB}$ family DNA binding. Nat Immunol 2011;13:95-102.

28. Espinosa L, Ingles-Esteve J, Robert-Moreno A, Bigas A. IкB $\alpha$ and p65 regulate the cytoplasmic shuttling of nuclear corepressors: Cross-talk between Notch and NFkB pathways. Mol Biol Cell 2003;14:491-502.

29. Wei H, Gao HQ, Li HB, Qi SJ, Liu WL, Xu L, et al. Correlation among RKIP expression, NFאB p65 levels, and T-lymphocyte subsets in gastric cardia adenocarcinoma. Genet Mol Res 2015;14:16491-6. 